\title{
ФІЛОСОФІЯ ЗДОРОВ'Я ЯК ЦІННІСНА КАТЕГОРІЯ У КОНТЕКСТІ ПАТРІОТИЧНОГО ВИХОВАННЯ МОЛОДІ В УКРАЇНІ
}

\author{
В. Й. Кульчицький
}

\author{
ДВНЗ “Тернопільський державний медичний університет \\ імені I. Я. Горбачевського МОЗ України”
}

\section{HEALTH PHILOSOPHY AS A VALUE CATEGORY IN THE CONTEXT OF PATRIOTIC EDUCATION OF YOUTH IN UKRAINE}

\author{
V.Y. Kulchytskyi \\ SHEI "Ternopil State Medical University by I. Ya. Horbachevsky of MPH of Ukraine"
}

\begin{abstract}
У статті проведено ретроспективний аналіз та обгрунтовано роль філософії здоров'я у контексті патріотичного виховання молоді в Україні; зосереджено увагу на тому, що здоров'я людини є складовою глобального значення, що може розглядатися як філософська, соціальна, педагогічна, економічна, біологічна, медична категорії, як об'єкт споживання, як додатковий капітал, як індивідуальна і суспільна цінності, явище системного характеру, динамічне, постійно взаємодіюче з оточуючим середовищем; охарактеризовано важливу роль системи фізичного виховання у формуванні ідейно і фізично досконалої особистості; зроблено висновки про те, що психолого-педагогічна наука особливе місце відводить вихованню молодої людини-патріота, яка веде здоровий спосіб життя.
\end{abstract}

The role of health philosophy in the context of patriotic education in Ukraine within retrospective analysis is substantiated in the article; attention is focused on the fact that human health is a part of global value that can be seen as a philosophical, social, educational, economic, biological, medical categories as object of consumption, as additional capital, as individual and social values, phenomenon of systemic nature, which dynamically interacts with the environment; the important role of physical education in forming the ideologically and physically perfect person is described; it was concluded that the psychological and pedagogical science devotes a special place to patriotic education of youth who live a healthy lifestyle.

Вступ. Здоров'я людини є найважливішим чинником соціокультурного розвитку і в той же час саме залежить від соціальних умов, в яких визначається його родова сутність. Без цього неможливе відчуття повноти людського життя, оптимальне задоволення психофізіологічних і економічних потреб. Здоров'я є досить складним предметом для наукового аналізу, переплетенням суб'єктивних і об'єктивних сторін життєдіяльності людини, що і констатує філософія здоров'я.

Філософія здоров' я - це осмислення людської сутності, як єдиної, збалансованої багатомірної біоенергоінформаційної системи, яка саморегулюється та самовідновлюється, в поєднанні з духовними, психічними, фізичними та соціальними аспектами ії життедіяльності, на основі гармонії та порядку [1].

У даний час доводиться констатувати відсутність загальноприйнятого трактування поняття “'здоров’ я”.

(с) В. Й. Кульчицький
Різноманіття поглядів на сутність поняття “здоров' я” i безуспішність спроб виробити єдину, погоджену думку значною мірою пояснюється тим, що здоров’я є досить складною ціннісною категорією, характерні і значимі сторони якої важко виразити коротко i однозначно. У той же час ефективне вирішення проблеми здоров' я можливе лише на основі міждисциплінарного підходу.

В умовах радикальної соціально-політичної трансформації нашого суспільства, коли відновлюється державність, відродження багатогранного культурно-історичного досвіду та традицій національного виховання надзвичайно активізувалася проблема духовного і фізичного розвитку молодого покоління, становлення його як соціальної особистості. Як здоров'я населення віддзеркалює минуле та сьогодення країни, так і її майбутнє безпосередньо залежить від здоров'я молоді [9]. 
У сучасних умовах зниження духовного потенціалу та здоров'я молоді стає відчутною реальністю необхідність формування їхніх духовних потреб, здорових звичок, фізичного загартування, в цілому здорового способу життя - одного з пріоритетних напрямів діяльності сучасної освіти України. У державних документах (Національна програма патріотичного виховання населення, формування здорового способу життя, розвитку духовності та зміцнення моральних засад суспільства (1999), Національна доктрина розвитку фізичного виховання і спорту (2004), Національна доктрина розвитку фізичної культури i спорту на 2005-2008 роки та ін.) зазначається, що кожна людина має право на здоров'я та здоровий спосіб життя. Саме тому формування здорового способу життя кожного громадянина є предметом уваги педагогічної науки, зокрема у процесі патріотичного виховання, адже: “здорова людина-здорова нація”. Так, Л. Сущенко підкреслює, що хоча психолого-педагогічна наука має величезне значення для прищеплення цінностей здорового способу життя особистості у процесі iї становлення, але вона не вбирає всіх багатогранних виховних засобів, що $є$ в її арсеналі. Отож, формування здорового способу життя молоді $є$ однією 3 актуальних проблем нашого суспільства.

Означена проблема знайшла своє відображення в багатьох педагогічних, медичних та соціологічних працях вчених (Б. Бутенко, В. Крамар, О. Гладощук, В. Оржеховська, О. Вакуленко, В. Слободяник, Л. Лепіхова, Т. Титаренко, О. Балакірєва та ін.).

Аналіз наукових праць свідчить про відсутність однозначного підходу до проблеми формування здорового способу життя. Проте різні визначення, класифікації здоров'я, здорового способу життя в цілому не суперечать одне одному, а навіть взаємодоповнюють, взаємопідсилюють і дозволяють розглядати їх з різних позицій. Так, різні напрями виховної роботи по формуванню здорового способу життя розробляли Г. Власюк, О. Дубогай, В. Кузь, С. Свириденко, А. Турчак; психологічні особливості виховання особистості розглядали І. Бех, Н. Максимова, С. Масгутова, І. Нікітіна, Р. Пасічняк, І. Романишин, М. Савчин, Л. Ульяницька; питанням формування ціннісних орієнтацій підлітків приділяли увагу С. Лапаєнко, О. Турянська, К. Шамлян; становлення соціальної активності підлітків знайшло відображення у працях К. Власова, В. Землянухіна, М. Китаєва, О. Карпенко, Н. Пономарчука тощо [9].

Метою нашої статті $є$ обгрунтування важливості філософії здоров'я у контексті патріотичного виховання молоді в Україні як ціннісної категорії.
Основна частина. Здоров'я людини є складовою глобального значення, що може розглядатися як філософська, соціальна, педагогічна, економічна, біологічна, медична категорії, як об'єкт споживання, як додатковий капітал, як індивідуальна і суспільна цінності, явище системного характеру, динамічне, постійно взаємодіюче $з$ оточуючим середовищем.

Об'єктивні характеристики здоров'я завжди виражені у суб'єктивній, навіть віртуальній формі. Відчуття благополуччя $є$ умовою творчого початку в людині. Здоров'я слід розглядати як творчість, яка включає відчуття віртуальності і справжньої реальності, пов'язаної з розкриттям внутрішніх резервів людини [5].

Сутність людини виявляється через діяльність, творчість та активність, які характеризують ії здоров'я. Гуманітарна доктрина освіти, спроектована на проблему здоров'я, дозволяє розкрити здоров'я як гуманітарну цінність. Тому філософія здоров'я розглядає здоров'я як цінність тою мірою, в якій допомагає розкрити людські якості, прагнення до самовдосконалення та до творчої активності [3].

Психолого-педагогічна наука, досліджуючи поняття “здоров'я", розглядає його, у першу чергу, у ракурсі здорової життєдіяльності як засобу самовдосконалення та самоактуалізації особистості в цілях іiі реалізації у соціумі (сімейно-побутовій, професійній, дозвільній та інших сферах), формує особистісну позицію, особистісний сенс, який є мірою ціннісно-смислового відображення дійсності.

Здоров'я людини визначається комплексом біологічних (спадкових і набутих) і соціальних факторів. Останні мають настільки важливе значення у підтримці стану здоров'я або в появі і розвитку хвороби, що у преамбулі статуту ВООЗ записано : “Здоров'я - це стан повного фізичного, духовного і соціального благополуччя, а не тільки відсутність хвороб і фізичних вад” [2].

Таке визначення поняття “здоров'я” $є$ найбільш чітким, зрозумілим, повним і вміщує, насамперед, біологічні, соціальні та психологічні аспекти даної проблеми.

Світова наука розробила цілісний погляд на здоров'я як феномен, що інтегрує принаймні чотири його сфери або складові - фізичну, психічну (розумову), соціальну (суспільну) і духовну. Всі ці складові невід'ємні одна від одної, вони тісно взаємопов' язані i саме разом, у сукупності, визначають стан здоров'я людини. Для зручності вивчення, полегшення методології дослідження феномену здоров'я наука диференціює поняття фізичного, психічного, соціального і духовного здоров'я [4]. 
Сучасні дослідження здоров’я грунтуються на біопсихоекологічній парадигмі, згідно з якою здоров'я детермінується біологічними, психологічними чинниками та впливом середовища [6].

Резерв у збереженні здоров'я людини закладений в організації способу життя, залежного від культури здоров’ я, що включає знання індивідом генетичних, фізіологічних, психологічних можливостей свого організму, методів контролю, збереження психофізіологічного стану і зміцнення здоров'я, уміння розповсюджувати медико-біологічні знання на своє оточення і в цілому на соціальне середовище.

Спосіб життя людини - це сукупність матеріальних умов, суспільних соціальних установок (культура, освіта, традиції тощо), умов поведінки (включаючи соціально-психологічну та фізіологічну активність) особистості. 3 позицій розуміння феномену здоров'я людини походить визначення поняття здорового способу життя: це все в людській діяльності, що стосується збереження і зміцнення здоров'я, все, що сприяє виконанню людиною своїх людських функцій через діяльність з оздоровлення умов життя - праці, відпочинку, побуту [7]. Таким чином, здоровий спосіб життя містить різноманітні елементи, що стосуються усіх сфер здоров'я - фізичної, психічної, соціальної і духовної. Здоровий спосіб життя передбачає дотримання виконання певних правил, що забезпечують гармонійний розвиток, високу працездатність, духовну рівновагу та здоров'я людини.

Проблема формування здорового способу життя досить ретельно висвітлюється в багатьох соціальнофілософських, педагогічних, соціологічних, медичних працях. Особливої актуалізації ця проблематика набула у другій половині ХХ століття як у світі в цілому, так і в Україні.

Тенденції розвитку країн колишнього Радянського Союзу протягом 80-90-х років ХХ століття змусили суспільство по-новому поставитись до складових здоров'я та формування здорового способу життя, зокрема молодого покоління. Слід підкреслити, що цим питанням приділяють увагу різні науки - медицина, гігієна, охорона здоров'я, екологія, педагогіка, психологія, соціологія, фізична культура, валеологія.

Рівень здоров'я, як правило, безпосередньо пов'язаний з рівнем освіти та виховання. Чим вищий середній рівень освіти в певному соціальному середовищі, тим кращі узагальнені показники здоров' я він демонструє. Природно, що піклування про власне і громадянське здоров'я неможливе без знання того, чому це необхідно і як це робити. Притому доцільно розуміти поняття освіти в даному контексті не тільки як освіту суто валеологічну, а значно ширше - як загальну освіту в цілому. Чим ширше знання основних природничих, наукових, філософських, гуманітарних положень, тим більше можливостей створювати у суспільстві системне уявлення про проблему здоров'я взагалі. Крім того, поняття освіти потрібно розуміти комплексно: і як надання інформації, і як навчання методів, прийомів і навичок здорового способу життя, і як виховання в дусі безумовного пріоритету цінностей індивідуального і громадянського здоров'я в усіх його проявах, сферах, рівнях.

Саме тому, виходячи із загальної мети радянського виховання - формування всебічно розвиненої особистості, - одним із першочергових завдань педагогічної науки стало обгрунтування і конкретизація завдань комуністичного виховання. У його виконанні тогочасні педагоги виявили традиційну одностайність з класиками педагогіки і якихось суттєвих розбіжностей у їх тлумаченні не появилося.

Так, автори книги “Основні питання педагогіки” (1957) М. Константинов, М. Смирнов, О. Савич зазначали, що мета комуністичного виховання досягається розв'язанням низки завдань: 1) дати новим поколінням розумове виховання або освіту; 2) забезпечити політехнічне навчання; 3 ) фізичне виховання; 4) морально-патріотичне виховання; 5) естетичне виховання [10]. "Гармонійний розвиток фізичних i духовних здібностей людини в умовах соціалізму, комунізму неможливий без поєднання патріотичного виховання з розумовою і фізичною працею", -зазначалося у посібнику з педагогіки С. Збандуто [11].

Партійна ідеологія не оминула й фізичне виховання школярів: "Партія вважає одним $з$ найважливіших завдань - забезпечити виховання, починаючи з раннього дитячого віку, фізично міцного молодого покоління з гармонійним розвитком фізичних і духовних сил. Це потребує всілякого заохочення усіх видів масового спорту і фізичної культури, в тому числі в школах, залучення до фізкультурного руху дедалі ширших верств населення, особливо молоді', - стверджується у Програмі КПРС 1964 р. [12].

Підкреслюючи важливу роль системи фізичного виховання у формуванні ідейно і фізично досконалого “будівника комунізму”, радянські педагоги особливе місце відводили вихованню молодої людини-патріота, яка веде здоровий спосіб життя.

Формами патріотичного виховання підлітків у процесі фізкультурно-масової роботи було визначено: туристські походи місцями бойової і спортивної слави земляків з відвідуванням музеїв; спортивні змагання на призи відомих людей і місцевих спортсменів; 
військово-патріотична спортивна гра "Зірниця"; відвідування місць поховань загиблих воїнів і догляд за могилами; зустрічі з учасниками й очевидцями Великої Вітчизняної війни; святкування річниць Перемоги у Великій Вітчизняній війні; свято “Мова рідна, слово рідне" тощо [8].

Однією з основних форм патріотичного виховання молоді у процесі фізкультурно-масової роботи були туристські походи. Вони організовувалися з метою активного відпочинку, заохочення до здорового способу життя; розширення у підлітків моральноціннісних орієнтацій; зміцнення тілесного й духовного здоров’я; розвитку основних фізичних якостей; загартування характеру; закріплення нових знань; проведення в походах суспільно корисної та пошукової роботи; забезпечення єдності цінностей здоров'я школярів з їхніми морально-духовними цінностями.

Зміст туристських походів спрямовувався на те, щоб у молодої людини формувався інтерес до фізкультурно-масової, суспільно корисної та патріотичної діяльності. У процесі туристських походів учні знайомилися з емоційно-привабливими формами роботи, різними умовами життя й побуту односельчан та міського населення свого регіону.

Сприяли вирішенню поставлених завдань 3 патріотичного виховання також змагання на призи відомих спортсменів, які організовувалися до днів їхнього народження, визначних дат, народних свят. Під час їх проведення стимулювалася мотивація підлітків, підвищувалася їхня активність, ініціативність, винахідливість. Для забезпечення ефективності колективних дій молоді люди дотримувалися відповідних соціонормативних вимог. Вони полягали в тому, щоб зміст спортивних змагань відповідав завданням патріотичного виховання; щоб під час проведення спортивних змагань ураховувалися психологічні, фізіологічні, вікові та статеві особливості старших підлітків, дотримувалися моральні норми поведінки; щоб у процесі організації змагань учні поступово готувалися до майбутньої професійної діяльності [8].

Ефективною формою патріотичного виховання старших підлітків експериментальних класів була військово-патріотична спортивна гра "Зірниця". У процесі підготовки й проведення гри учні отримували відповідні знання, у них формувалися уміння, необхідні їм як майбутнім захисникам Вітчизни. Підготовка до гри “Зірниця” із молоддю відбувалася на уроках фізичної культури і в позанавчальний час напередодні Дня Перемоги. Особливого значення надавалося залученню до проведення військово-патріотичної спортивної гри “Зірниця” відомих людей села чи міста, а також й усіх бажаючих. Важливою умовою було й залучення на фінал гри очевидців бойових дій, батьків, членів родин, учителів, які свого часу брали участь у “Зірниці".

У середині 90-х років ХХ століття в Україні з'являється скаутська організація "Пласт". Мета Пласту - сприяти всебічному, патріотичному вихованню та самовихованню української молоді на засадах християнської моралі та здорового способу життя. Будучи неполітичною і позаконфесійною організацією, Пласт виховує молодь на свідомих, відповідальних і повновартісних громадян місцевої, національної та світової спільноти, провідників суспільства.

Протягом року Пласт в Україні проводить понад 100 виховних таборів різної спеціалізації: спортивні, морські, з повітроплавання, мистецькі, лижні, альпіністичні, археологічні, кінні, екологічні тощо. У таборах пластуни практично закріплюють знання і уміння, здобуті впродовж року на щотижневих заняттях. Серед найбільших заходів, котрі щороку проводяться Пластом на всеукраїнському рівні, - інтелектуально-мистецьке змагання Орликіада, фестиваль творчості День пластуна, спортивне змагання Спартакіада, передача Вифлеємського вогню місцевим громадам, змагання з пішого мандрівництва “Стежками героїв” та “Осінній рейд”. На місцевому рівні осередками Пласту постійно реалізується безліч акцій соціально-культурного, патріотичного та виховного спрямування [13].

Одним із перших законодавчих актів з питань патріотичного виховання був Указ Президента України 'Про заходи щодо розвитку духовності, захисту моралі та формування здорового способу життя громадян” від 27 квітня 1999 р. № 456, на підставі якого постановою Кабінету Міністрів України від 15 вересня 1999 р. № 1697 була затверджена Національна програма патріотичного виховання громадян, формування здорового способу життя, розвитку духовності та зміцнення моральних засад суспільства, одне 3 головних завдань якої - забезпечення формування та розвитку у молоді загальнолюдських і національних цінностей. Програма передбачала реалізацію низки заходів, спрямованих на фізичне і духовне гартування молоді, зокрема впровадження серед учнівської молоді гри-випробування “Котигорошко” (виховання молоді на українських традиціях і формування в неї здорового способу життя) [14]. Для посилення Національної програми у 2001 р. було видано розпорядження Президента України "Про заходи щодо подальшого вдосконалення системи патріотичного виховання молоді” № 173/2001-рп, згідно з яким під 
час формування Державного бюджету України на 2002-й і наступні роки обов'язково планувалися кошти, необхідні для виконання цієї програми [15].

Метою державної системи патріотичного виховання $\epsilon$ відродження в українському суспільстві громадянськості, патріотизму як важливіших духовноморальних і соціальних цінностей, формування і розвиток свідомості та самосвідомості молодого покоління, яке володіє важливішими громадянськими, активними, соціально значними рисами, здатними проявити їх у процесі творення в інтересах нашого суспільства, в укріпленні і удосконаленні його основ.

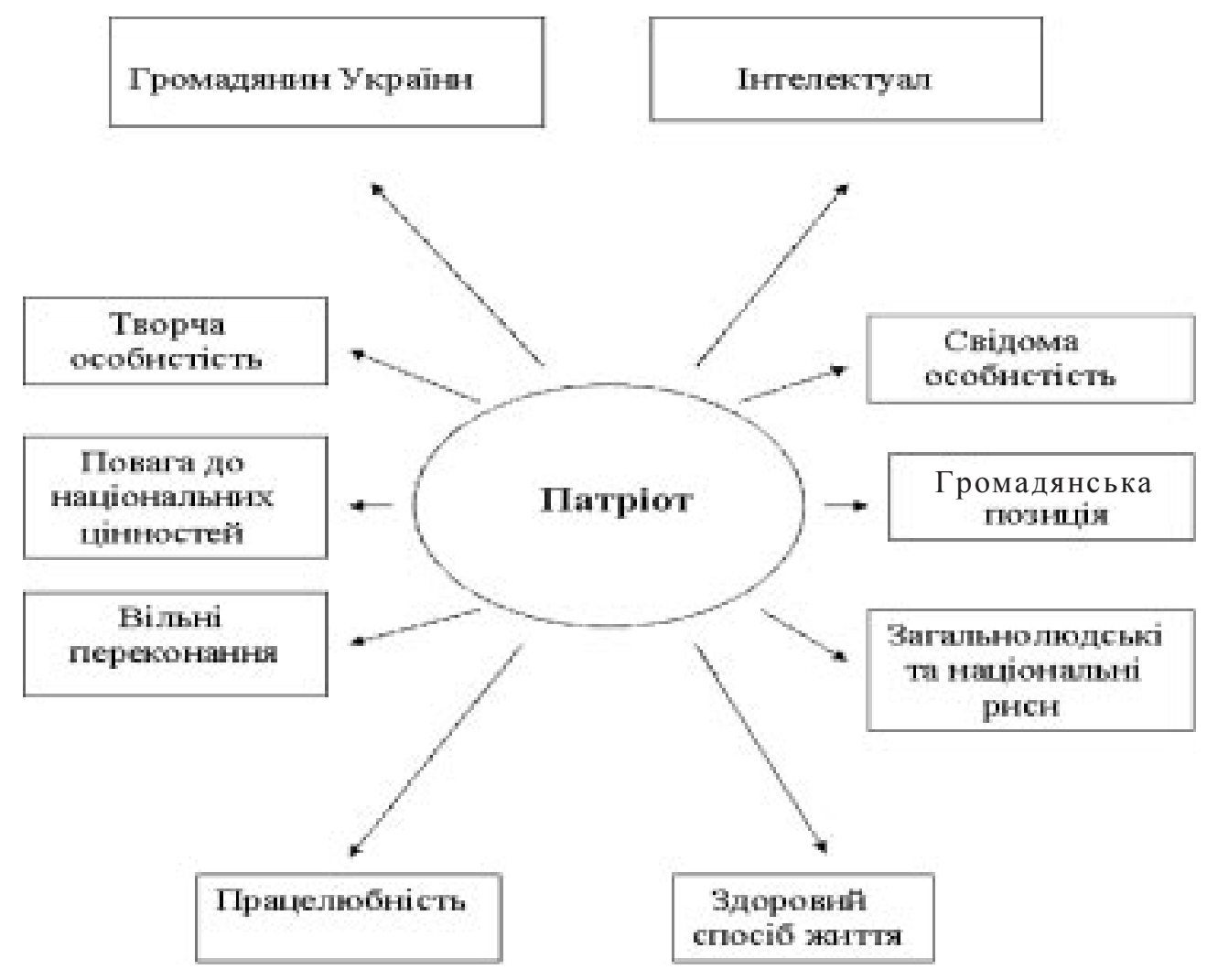

Рис. 1. Завдання патріотичного виховання.

Висновки. Отже, філософія здоров'я розглядає сутність людини як певний потенціал, який має бути реалізований у процесі існування людини. Але, на нашу думку, здоров'я та здоровий спосіб життя потребують на сучасному етапі розвитку суспільства найбільш інтегрованого, соціально-філософського підходу до проблем здоров'я, необхідності формування свідомості, зокрема патріотичної, слідувати нормам здорового способу життя, розуміння інтеграції складових здоров'я людини: фізичної, психічної, духовної, соціальної.

Беззаперечним є той факт, що в сучасній Україні здоров'я $€$ важливою ціннісною категорією у струк-
Із загальної мети цього напрямку виховання витікають наступні завдання (рис. 1).

Таким чином, проаналізувавши рисунок 1 , ми можемо зробити висновок про те, що одним із завдань патріотичного виховання є формування у молодої людини уміння вести здоровий спосіб життя, як важливу складову процесу розвитку людини, що передбачає підготовку до високопродуктивної праці, запобігання антигромадським проявам, підготовку до захисту Батьківщини, забезпечення іiї творчого довголіття, організація здорового та змістовного дозвілля. 


\section{Списоклітератури}

1. Амосов М. М. Здоров'я / М. М. Амосов. - К. : Нива, 1997. $-142 \mathrm{c}$.

2. Апанасенко Г. Л. Избранные статьи о здоровье / Г. Л. Апанасенко. -К. : Здоров’я, 2005. -48 с.

3. Ложкин Г. В. Психология здоровья человека / Г. В. Ложкин, О. В. Носков, И. В. Толкунова. - Севастополь : Вебер, 2003. $-257 \mathrm{c}$.

4. Коцан І. Я. Психологія здоров’я людини : навчальний посібник / І. Я. Коцан, Г. В. Ложкін, М. І. Мушкевич. - Луцьк : РВВ Вежа Волинського національного університету ім. Лесі Українки, 2011.-430 с.

5. Путров С. Ю. Здоров'я у контексті предметного самовизначення філософії / С. Ю. Путров // Гуманітарний вісник ЗДІА.-2013. - № 55. - С. 152-162.

6. Власов Г. В. Фізичне виховання як основа професійного становлення фахівців медичних закладів / Г. В. Власов // Педагогіка, психологія та медико-біологічні проблеми фізичного виховання і спорту. - 2010. - № 1.-С. 29-32.

7. Гуров В. А. Здоровый образ жизни: научные представления и реальная ситуация / В. А. Гуров // Валеология. -2006. - № 1.- С. 53-59.

8. Тимчик М. В. Патріотичне виховання старших підлітків у процесі фізкультурно-масової роботи : дис. ... кандидата пед. наук: спец. 13.00.07 “Теорія і методика виховання" / Микола Валерійович Тимчик. - К. : НАПН України, Ін-т проблем виховання, 2012. - 222 с.
9. Вакуленко О. В. Здоровий спосіб життя як соціальнопедагогічна умова становлення особистості у підлітковому віці: дис. . . . кандидата пед. наук: спец. 13.00.05 “Соціальна педагогіка" / Олена Василівна Вакуленко. - К. : Національний педагогічний університ імені М. П. Драгоманова, 2001.-178 c.

10. Константинов Н. А. Основные вопросы педагогики / Н. А. Константинов, А. Л. Савич, М. Т. Смирнов. М. : Учпедгиз, 1957.-312 с.

11. Збандуто С. Ф. Педагогіка / С. Ф. Збандуто. К. : Радянська школа, 1965.-508 с.

12. Програма КП СРСР.-К. : Держполітвидав УРСР, 1961. 13. Чупрій Л. В. Патріотичне виховання молоді в контексті забезпечення гуманітарної безпеки держави / Л. В. Чупрій // Стратегічні пріоритети. - 2011. - № 2. C. $67-72$.

14. Постанова Кабінету Міністрів України від 15 вересня 1999 року № 1697 : Національна програма патріотичного виховання громадян, формування здорового способу життя, розвитку духовності та зміцнення моральних засад суспільства // Директор школи. - 2003. - № 29-32. - С. 16-18.

15. Розпорядження Президента України від 29 червня 2001 року № 173 : Про заходи щодо подальшого вдосконалення системи патріотичного виховання молоді // Уряд. кур'єр. -2001.-5 липня. -С. 10. 